\title{
CAN WE USE ORIGAMI FOLDING AS AN EFFECTIVE INSTRUMENT FOR DEVELOPING ALGORITHMIC THINKING OF BLIND PUPILS?
}

\section{L'udmila Jašková}

\begin{abstract}
Paper deals about our experience with developing algorithmic thinking of blind secondary school pupils through the folding orgiami. We define informatics concepts which are possible to build this way. We put emphasis on finding appropriate instructions understandable for the blind, to be used for mediation procedure for folding origami. We suggest the suitable orgiami for the blind. Suitability is judged by whether it is possible only on the basis of tactile perception to understand their shape and purpose and whether they can be put together without visual control. At the end we give methodological recommendations for teachers who plan to use the method of folding origami in their informatics lessons with blind and also sighted pupils.
\end{abstract}

Key words: algorithmic thinking, blind, origami.

\section{MOŽNO POUŽIŤ METÓDU SKLADANIA ORIGAMI AKO EFEKTÍVNY NÁSTROJ NA ROZVOJ ALGORITMICKÉHO MYSLENIA NEVIDIACICH ŽIAKOV?}

Resumé: V článku popisujeme naše skúsenosti s rozvojom algoritmického myslenia nevidiacich žiakov druhého stupňa ZŠ metódou skladania origami. Najprv uvádzame informatické koncepty, ktoré sa dajú metódou skladania origami u detí budovat'. Dôraz kladieme na hladanie vhodných inštrukcií zrozumitel'ných pre nevidiacich, ktoré je potrebné použit' na sprostredkovanie postupu pri skladaní origami. Zamýšl’ame sa nad tým, ktoré orgiami sú vhodné pre nevidiacich. Vhodnost' posudzujeme podl'a toho, či je možné len na základe hmatového vnímania pochopit’ ich tvar a účel a či je možné ich poskladat' bez zrakovej kontroly. V závere uvádzame metodické odporúčania pre učitel'ov, ktorí plánujú metódu skladania orgiami použit’ na hodine informatiky s nevidiacimi, ale aj vidiacimi žiakmi.

Kl'účové slová: algoritmické myslenie, nevidiaci, origami.

\section{1 Úvod}

Od septembra 2011 vyučujeme informatiku na základnej škole pre deti s poruchami zraku. Súčast’ou informatiky je aj rozvoj algoritmického myslenia a programátorských zručností [20]. Už v ŠVP pre prvý stupeň základnej školy [19] ako súčast' obsahového štandardu predmetu informatická výchova nájdeme "skladanie podla návodov (stavebnice, hlavolamy, origami)". Metódu skladania origami by mal teda učitel' informatiky vediet' vhodne využit' na svojom predmete. Ide o činnost', ktorú je možné vykonávat' bez počítačov a dokážu ju vykonávat' žiaci l'ubovol'ného veku a schopností.

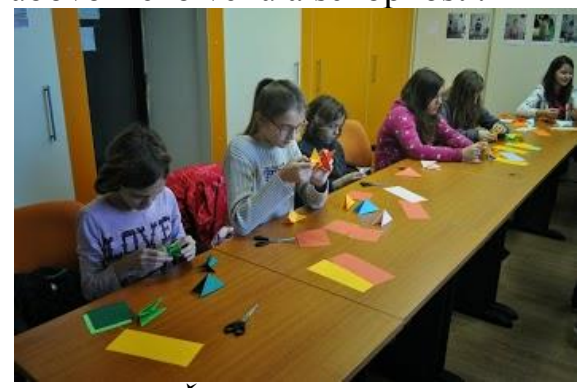

Obr 1: Žiaci skladajú origami
$\mathrm{V}$ škole pre deti s poruchami zraku je rôznorodé zoskupenie žiakov - nevidiaci žiaci, slabozrakí žiaci, vidiace deti s poruchami učenia, prípadne s inými dysfunkciami, kvôli ktorým sa vzdelávajú $\mathrm{v}$ menších kolektívoch $\mathrm{s}$ možnost'ou individuálneho prístupu.

Pokial' je to možné, všetky tri typy žiakov používajú na informatike rovnaký softvér, ale pracujú s ním rôznym spôsobom. Nevidiaci žiaci však nemôžu niektoré aktivity $\mathrm{s}$ počítačom vykonávat' tak ako vidiaci (napríklad práca $\mathrm{s}$ grafikou, s videom). V tomto smere sa cítia byt' diskriminovaní, pretože vidiaci žiaci práve tieto aktivity najviac oblubujú a radi sa chvália výsledkami svojej tvorivej činnosti pred spolužiakmi. Oceňujeme preto také typy aktivít, ktoré sú vhodné pre všetkých žiakov. Medzi ne patrí pravdepodobne aj skladanie origami. Pokúsili sme sa preskúmat', či dokážu skladat' origami aj úplne nevidiace deti. Použitú výskumnú metódu popisujeme v nasledujúcej kapitole. V tretej časti sa zamýšllame nad tým, 
aké informatické kompetencie môžeme metódou skladania origami rozvíjat'. V štvrtej uvádzame prehlad informácií týkajúcich sa skladania origami nevidiacimi, ktoré sme našli v literatúre a na webe. $\mathrm{V}$ piatej časti popisujeme vzdelávací scenár, ktorý sme vytvorili a použili s našimi nevidiacimi žiakmi. V šiestej sa podelíme o naše skúsenosti $\mathrm{s}$ využitím tohto scenára so sledovanou skupinou žiakov. V závere zhrnieme najdôležitejšie výsledky a prediskutujeme námety na využitie metódy skladania origami s nevidiacimi aj bežnými žiakmi.

\section{Použité výskumné metódy}

Našim ciel'om bolo nájst' odpovede na nasledujúce otázky.

1. Sú orgiami vhodné na rozvoj algoritmického myslenia detí?

2. Dokážu origami úspešne skladat' nevidiaci?

3. Aké orgiami použit's nevidiacimi, aby boli dostatočne motivujúce?

4. Aké orgiami použit' s nevidiacimi, aby boli tvary výsledných predmetov pre nich dostatočne zrozumitel'né?

5. Aké inštrukcie treba použit' pri inštruovaní nevidiacich žiakov počas skladania?

6. Dokážu nevidiaci žiaci dostatočne presne vykonávat' inštrukcie?

7. Dokážu nevidiaci žiaci hmatom dostatočne vnímat' potrebné zhyby a hrany papiera?

Odpovede na prvé dve otázky sme hl'adali okrem iného aj v dostupnej literatúre. Komentovaný prehl'ad uvádzame v nasledujúcich dvoch kapitolách.

Okrem štúdia literatúry sme použili metódu výskumu vývojom. Jedná sa o intervenčnú výskumnú stratégiu, ktorá si kladie za ciel' skúmat' a vyvíjat' zároveň [5]. Vyvíjali sme metodický materiál slúžiaci na rozvoj algoritmických kompetencií pomocou metódy skladania origami, ktorý sme overili $\mathrm{v}$ rámci vyučovania. Následne sme analyzovali naše pozorovania a na základe zistení sme sformulovali odporúčania na modifikáciu metodiky a teóriu o tom, nakol'ko je skladanie orgiami vhodné pre rozvoj algoritmického myslenia.

Ako výskumnú metódu na zber dát sme použili zúčastnené pozorovanie. Učitel' bol zároveň pozorovatel'om. Po odučenej hodine si urobil podrobné poznámky a tie potom analyzoval.

Náš vzdelávací scenár, ktorý popisujeme v časti 5, prešiel dvomi iteráciami. Overovanie sme realizovali v každej iterácii s inou skupinou žiakov. Každá iterácia pozostávala z niekol'kých krokov: overovanie vzdelávacieho scenára na vyučovacej hodine, analýza a vyhodnotenie dát, modifikácia vzdelávacieho scenára.

V prvej iterácii tvorili našu výskumnú skupinu štyri nevidiace žiačky piateho a šiesteho ročníka (10 až 12 rokov). Dve $\mathrm{z}$ nich boli nevidiace od narodenia a jedna náhle stratila zrak ako šest'ročná. V skupine bola jedna piatačka a tri šiestačky. Všetky štyri dievčatá mali informatiku prvýkrát v piatom ročníku. Počas prvého stupňa ZS predmet informatická výchova neabsolvovali a nemali žiadne skúsenosti so skladaním origami. Podobne aj s počítačom začali pracovat' až v piatom ročníku. Význam slova origami však poznali.

V druhej iterácii sme scenár realizovali so skupinou troch nevidiacich žiakov (1 chlapec, 2 dievčatá). Jedna žiačka bola nevidiaca od narodenia, jedna bola so zvyškami zraku a jeden žiak stratil zrak v priebehu života. Dvaja žiaci boli $\mathrm{v}$ piatom ročníku a počas celého prvého stupňa mali predmet informatická výchova. Jedna žiačka bola $v$ šiestom ročníku a tá mala informatiku prvýkrát $\mathrm{v}$ piatom ročníku

S každou skupinou sme náš vzdelávací scenár overovali počas dvoch na seba nadväzujúcich vyučovacích hodín.

\section{Origami a informatické kompetencie}

Metódu skladania origami je možné v procese vzdelávania použit' $\mathrm{v}$ rámci rôznych predmetov. Napríklad v rámci pracovného vyučovania možno pomocou skladania origami rozvíjat' motorické zručnosti. V rámci výtvarnej výchovy sa môže rozvíjat' umelecká tvorivost'. Okrem toho má táto činnost' terapeutické a relaxačné účinky. Na biológii si žiaci môžu vytvorit' papierové zvieratká a zopakovat' pri tom ich charakteristické vlastnosti. V rámci matematiky sa pomocou skladania origami rozvíjajú vedomosti o geometrických tvaroch, symetrii, rozvíja sa priestorová predstavivost' a presnost'. 


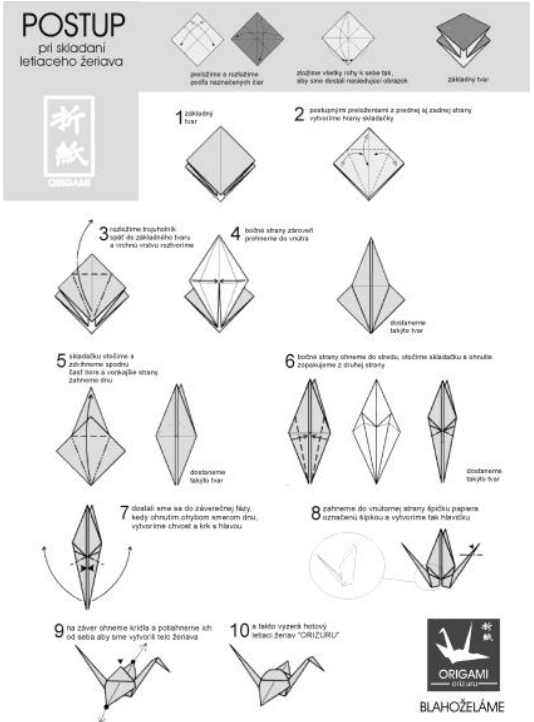

Obr 2: Obrázkový návod na skladanie origami žeriava (originál je na www.cvczh.edu.sk/cvc/projekty/origami)

$\mathrm{V}$ rámci informatiky sa dôraz kladie na popis presného postupu, ktorý treba dodržat' pri skladaní origami, čo prispieva $\mathrm{k}$ rozvoju algoritmického myslenia. Žiaci môžu vytvárat' návody na skladanie alebo vykonávat' činnost' podla hotového návodu. Toto vedie $\mathrm{k}$ pochopeniu pojmov inštrukcia, postupnost' inštrukcií. Dôležité je zvolit' vhodný spôsob na zápis postupu. V dostupnej literatúre a na webe sa najčastejšie používajú nasledujúce štyri typy návodov na skladanie orgiami, ktoré považujeme za vhodné pre žiakov základnej školy.

- Textové návody. Postup je popísaný pomocou textu (obr. 4). Spravidla bývajú jednotlivé kroky uvedené v číslovanom zozname. Autori sa snažia o stručnost', ale aj dostatočnú názornost'.

- Obrázkové diagramy. Ide o postupnost' jednoduchých obrázkov ilustrujúcich stav skladačky v danom kroku (obr. 2). Často sa používajú šípky znázorňujúce smer v akom treba zohnút' papier. Obrázky niekedy bývajú doplnené aj stručnými inštrukciami vo forme textu.

- Animované návody. Jednotlivé kroky sú znázornené pohyblivými kreslenými obrázkami, ktoré znázorňujú požadované úkony s papierom.

- Video s nahovoreným slovným komentárom. Pomocou kamery sa nasníma osoba, ktorá skladá origami a zároveň slovne komentuje, čo robí. Dôležité je, aby bolo zretel'ne vidiet' pohyby rúk skladajúcej osoby.

Ak žiaci vytvárajú návody uvedených typov, okrem rozvoja algoritmického myslenia si precvičujú aj zručnosti potrebné pre prácu s textovým alebo grafickým editorom, prípadne programom určeným na spracovanie videa. Dobrou motiváciou je, ak starší žiaci vytvárajú návod pre mladších.

V dostupnej literatúre sme našli príklady využitia origami na rozvoj programátorských zručností. Napríklad Gabika Lovászová používa origami ako motiváciu pre deti, ktoré sa učia programovat' v prostredí Imagine. "Deti kreslia pomocou korytnačky obrázky inšpirované papierovými skladačkami” [7].

Orgiami používa na rozvoj programátorských zručností aj Jeanine Meyer. Podl'a nej „Vytváranie návodov pre skladanie origami je vynikajúcou príležitost'ou na použitie Flash $M X$ a jeho skriptovacieho jazyka ActionScript. Autorka použiva tento pristup vo svojom úvodnom kurze programovania na obchodnej akadémii SUNY, v rámci ktorého sa zameriava na programovanie hier" [8].

Problematike skladania origami sa venuje viacero výskumníkov. Sú vedecké práce zaoberajúce sa tvorbou formálneho jazyka pre zápis postupu skladania, napr. [18]. Takýto jazyk môže potom interpretovat' počítač alebo dokonca robot.

Napríklad Devin Balkcom, študent doktorandského štúdia robotiky na Carnegie Mellon Univerzite, $v$ rámci svojej dizertačnej práce vytvoril prvého robota na skladanie origami [1].

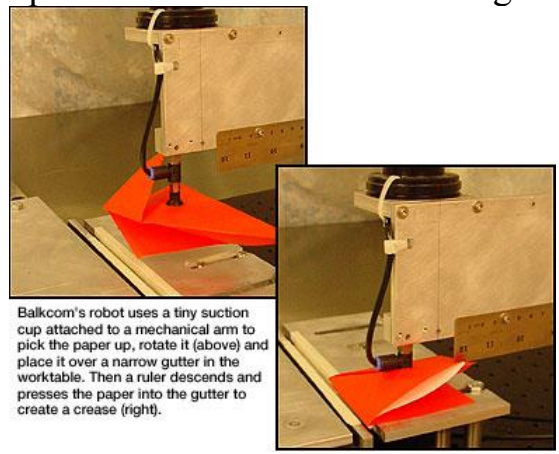

Obr 3: Balkcomov origami-robot [1]

Jazyk vhodný pre skladacieho robota však považujeme za príliš komplikovaný a preto nevhodný pre žiakov základnej školy. Hru na skladacieho robota však možno použit' ako motiváciu pre vzdelávacie aktivity s týmito žiakmi. 


\section{Origami a nevidiaci}

V odbornej a vedeckej literatúre sme nenašli žiadne informácie o využití origami $\mathrm{v}$ procese vzdelávania nevidiacich. $\mathrm{Na}$ webovej stránke Tyfloservisu v Hradci Králové nájdeme upútavku na Kurz hmatového vnímania pre l'udí so zrakovým postihnutím [21]. Základnou použitou metódou je skladanie origami. Začína sa hmatovou rozcvičkou, počas ktorej nevidiaci spoznávajú geometrické tvary. Potom účastníci pracujú s papiermi v tvare štvorca. Pracovníci Tyfloservisu sú presvedčení, že „, táto činnost môže nevidiacim pomôct', aby l'ahšie porozumeli slovnému popisu, ked' ich niekto navádza - či už je to profesionál alebo niekto, koho stretnú na ulici “. Samotní nevidiaci účastníci kurzu sú presvedčení, že im skladanie orgiami pomáha pri orientácii na dvojrozmernej pracovnej ploche.

$\mathrm{V}$ argentínskej provincii Salta nájdeme knižnicu so špeciálnou miestnost'ou vyhradenou pre nevidiacich. V tejto miestnosti si nevidiaci môžu čítat' alebo skladat' origami. $\mathrm{K}$ dispozícii je asistentka, ktorá im vysvetl'uje postup skladania tak, že každý krok najprv urobí so svojim papierom a nechá ich ohmatat' výsledok kroku. Oni potom tento krok vykonajú so svojim papierom [12].

Uvedené dva príklady dokumentujú, že skladanie origami sa používa ako vhodná aktivita pre nevidiacich. Rozvíja ich priestorovú predstavivost', jemnú motoriku a manuálnu zručnost' a domnievame sa, že aj algoritmické myslenie. Ako sme uviedli v úvode článku, vykonávanie návodov na skladanie origami je súčast'ou obsahového štandardu ŠVP pre prvý stupeň Z ̌̌s. Z hl'adiska nevidiacich detí je však vhodné zaradit' túto činnost' aj $v$ rámci vyučovania informatiky na druhom stupni. Podl'a [13] „sa ukázalo, že po verbálnej stránke niet rozdielov medzi vidiacimi a nevidiacimi, ale performačné úlohy riešia nevidiaci vo vyššom veku v porovnaní s vidiacimi. Napríklad úlohu reprodukcie štvorca a obdľžnika pomocou paličiek riešia nevidiaci až vo veku okolo 8-12 roku, kým vidiaci už okolo 4-6 roku“.

Pri vol'be origami skladačky je dôležité, aby výsledný objekt zodpovedal predstavám nevidiacich, ktoré majú o tomto objekte. Vytvorená skladačka je totiž modelom nejakého reálneho objektu. Z hl'adiska nevidiacich si treba uvedomit', že „,predstavivost' u žiakov s t'ažkým zrakovým postihnutím má svoje špecifické odlišnosti oproti intaktným. Najčastejšie sa jedná $o$ také rozdiely $v$ predstavách, ktoré neboli vytvorené prostrednictvom prisunu rovnakých podnetov. Predstavy o budovách, technických strojoch (ako napriklad žeriav), autách, prip. niektorých živočíchoch, rastlinách a podobne, môžu byt' u nevidiacich žiakov výrazne odlišné ako u intaktných" [3]. Je preto vhodné vytvárat' objekty, ktoré nevidiaci dobre poznajú z každodenného života a vytvorili si o nich predstavy na základe hmatového vnímania bud' samotného predmetu alebo jeho obrázka $v$ taktilnej podobe.

Z hl'adiska hmatového vnímania taktilných obrázkov si však treba uvedomit', že ,hmatové vnímanie neabstrahuje trojrozmerný priestor na dvojrozmerný obrys, spojenie hmatovej predstavy predmetu a jeho dvojrozmerného obrysu je pre nevidiaceho náročnejšie " [22].

Hmatové vnímanie označujú odborníci za „menej celistvé, ktoré sprostredkúva menšiu kvantitu ziskavaných podnetov v komparácii so zrakovým vnímanim “ [14]. Podl'a [15] ,je proces hmatového vnímania sukcesivny, poznávanie prebieha postupne, od častí k celku". Tento spôsob vnímania ̌̌ezníčková [15] označuje za časovo náročnejší a namáhavejší, pričom vyžaduje aktívnejšie zapojenie pozornosti, pamäte a myslenia.

V predchádzajúcej časti sme spomenuli štyri typy návodov na skladanie origami. Ktoré $\mathrm{z}$ nich sú vhodné aj pre nevidiacich?

Textové návody by mohli byt' vhodné pre nevidiacich, ak sú napísané tak, aby im dostatočne rozumeli. Takéto návody nájdeme napríklad na stránkach Jiř́ho Mojžíška [9], ktorý je sám nevidiaci a venuje sa skladaniu origami. Takýto návod nájdeme aj na stránkach spoločnosti WebAIM, ktorá sa venuje tvorbe prístupných webových stránok [23] alebo na stránkach British Origami Society [2].

\section{Čepice}

Základem je obdélník nastojato, výška aspoň o $5 \mathrm{~cm}$ větší než šiřka. 1. Dělíme výšku, ohýbáme dolů.

2.Dělíme šíŕku, ohýbáme doleva.

3. Dělíme pravý horní roh, dvojitý papír, ohýbáme zleva a shora.

4. Obrátíme podle svislé osy.

5. Dělíme levý horní roh,dvojitý papír, ohýbáme zprava a shora. 6. Otevřeme jako knihu zprava.

Obr 4: Čast' textového návodu pre nevidiacich na skladanie čiapky (originál je v [9])

Obrázkové návody nie sú vhodné pre nevidiacich. Je však možné vytvorit’ ich taktilnú verziu. Táto by však bola t’ažko zrozumitel'ná bez slovného komentára. Treba si totiž uvedomit', že „, hapticky je možné vnimat' iba predmety, ktoré sú 
hmatatelné - obsahujú rohy, okraje, čiary, rozdielne plochy vpodobe vyvýšených tvarov. V̌setky tieto faktory vytvárajú vzhl’ad obrázka. Okrem toho je vnimanie obrázka hmatom iné ako ked'sa vnima zrakom. Vidiaci človek vidi celý obrázok a jeho detaily naraz a dokáže urobit' mentálny skok k porozumeniu významu obrázka. Vnimanie obrázka hmatom je iné. Najprv sa poznávajú detaily, kúsok po kúsku a čast' po časti a pochopenie obrázka nastane až po preskúmani celého obrázka. Avšak, aby nastalo úplné pochopenie taktilného obrázka osobou, ktorá nemá skúsenosti stakýmito obrázkami, je potrebné vediet čo obrázok reprezentuje. Preto je vel'mi dôležité povedat' diet'at'u, čo je na obrázku a porozprávat' mu o všetkých objektoch na obrázku - kde sú umiestnené na ploche " [17].

Animované návody alebo návody vo forme videa sú pre vidiacich pravdepodobne najzrozumitel'nejšie. Pre nevidiacich sú nepoužitel'né. Ich alternatívou môže byt' postup, ktorý používajú v argentínskej provincii Salta (uviedli sme ho na začiatku tejto časti článku). Teda inštruktor skladá orgiami so svojim papierom a po každom kroku nechá nevidiaceho ohmatat', čo má byt' výsledkom daného kroku. Tento postup je pre nevidiacich začiatočníkov pravdepodobne najvhodnejší. Lahko sa použije, ak sa každému nevidiacemu môže venovat' jedna asistujúca osoba. Ak je však pre skupinu nevidiacich $\mathrm{k}$ dispozícii iba jeden asistent, výsledok každého kroku si postupne musí ohmatat' každý nevidiaci, čím sa činnost' niekol'konásobne predíži.

Z uvedeného vyplýva, že nevidiaci začiatočník zákonite potrebuje na skladanie dlhší čas ako vidiaci. Vidiaci človek môže napodobňovat' pri skladaní pohyby rúk inej skladajúcej osoby, na ktorú sa paralelne pozerá. Tiež môže zrakom skontrolovat', či postupoval pri skladaní správne. Nevidiaci musí tieto činnosti vykonávat' za sebou a len hmatom. Používa ruky aj na hmatové preskúmanie toho, čo má robit' a aj na vykonanie kroku a následne na hmatovú kontrolu správnosti vykonaného kroku.

\section{Vzdelávací scenár}

V tejto časti popíšeme našu metodiku, ktorú sme pripravili $\mathrm{v}$ rámci vyučovania témy Vykonávanie činnosti podl'a návodu. Našim ciel'om bolo, aby žiaci pochopili pojmy inštrukcia a postupnost' inštrukcií prostredníctvom skladania známych origami skladačiek - lod'ka, čiapka, srdiečko a pohárik.
Tieto objekty sme si zvolili $\mathrm{z}$ nasledujúcich dôvodov.

- Považujeme ich za dostatočne jednoduché.

- Podl'a tvaru sa dá hmatom l'ahko zistit' o aký objekt sa jedná.

- Ide o objekty, ktoré majú praktické využitie, prípadne sa dajú použit' ako darček, čo zvyšuje motiváciu žiakov.

Teraz bližšie popíšeme metodický postup.

Najprv sa žiakov opýtame, čo znamená slovo origami. Predpokladáme, že všetci vedia, že sa jedná o papierové skladačky. Tiež sa opýtame, či už skladali origami. Povieme im, že sa zahráme na robotov, ktorí podl'a presných inštrukcií vyrábajú z papiera užitočné a pekné predmety, napríklad čiapku, lod'ku a podobne. Ďalej sa opýtame, prečo sa tejto činnosti budeme venovat' na hodine informatiky. Sledujeme tým, aby si uvedomili, že pri skladaní musí robot dodržiavat' presný postup a jednotlivé kroky musí mat' zrozumitel'ne popísané.

Najprv budeme skladat' origami čiapku. Začneme tým, že žiaci preskúmajú hmatom hotovú čiapku, aby vedeli, čo idú skladat'. Pre lepšie pochopenie účelu výsledného objektu, si ju žiaci môžu dat' na hlavu,.

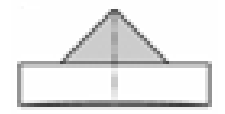

Obr 5: Origami čiapka

Pri skladaní postupujeme podl'a návodu uvedeného na obrázku 9. Dodržiavame pritom nasledujúce pravidlá.

- Na začiatku každého kroku musia mat' žiaci správne otočený papier.

- Pri každom kroku najprv slovne vysvetlíme, čo treba urobit' a necháme žiakov ohmatat', čo má byt' výsledkom.

- Snažíme sa, aby žiaci zvládli inštrukcie vykonat' samostatne.

- Ak je to potrebné, usmerníme slovne alebo dotykom pohyby ich rúk.

Ak sa žiakom podarí poskladat' čiapku, budú pravdepodobne schopní poskladat' aj lod'ku, pretože pri jej skladaní je prvých šest' krokov zhodných s postupom skladania čiapky.

Skladanie lod'ky opät' začneme tým, že žiaci preskúmajú hmatom hotovú lod'ku. Vysvetlíme si, čo to je a povieme si, že takáto lod'ka dokáže plávat' na vode. Predpokladáme, že zvedavost' a túžba preverit' toto tvrdenie bude pre žiakov dobrou motiváciou. 
Pri skladaní lod'ky postupujeme podl'a návodu uvedeného na obrázku 10, pričom prvých šest' krokov je identických ako pri skladaní čiapky. Pri skladaní lod'ky si teda žiaci zopakujú postup potrebný na skladanie čiapky. Dodržiavame rovnaké pravidlá ako pri skladaní čiapky.

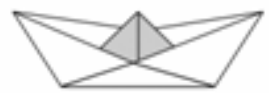

Obr 6: Origami lodka

Pri skladaní orgiami srdiečka využijeme, že sa blíži nejaký sviatok, v ktorý sa zvykne niekoho obdarovat' (napríklad Valentín, Deň matiek a podobne). Žiaci tak budú silne motivovaní vytvorit' srdiečko, ktoré darujú niekomu, koho majú radi.

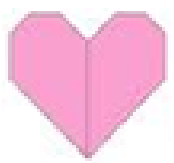

\section{Obr 7: Origami srdiečko}

Žiaci opät' preskúmajú hotové srdiečko hmatom. Predpokladáme, že sa bude zhodovat' s ich predstavou, ktorú majú o tvare srdca. Najprv môžu srdce skladat' $z$ bieleho papiera, aby si nacvičili postup skladania. Ked' ho ovládajú, poskladajú srdiečko z červeného papiera, ktoré niekomu darujú. Skladáme podla návodu uvedeného na obrázku 11, pričom dodržiavame pravidlá uvedené vyššie.

Origami pohárik považujeme za jednoducho vytvoritel'ný a užitočný zároveň. Iné v porovnaní s predchádzajúcimi skladačkami je, že sa používa papier v tvare štvorca a nie obdĺžnika. Je potrebné, aby žiaci vedeli z papiera formátu A4 vytvorit' papier tvaru štvorca, prípadne je vhodné mat' vopred pripravený papier požadovaného tvaru. Pri skladaní postupujeme podl’a návodu uvedeného na obrázku 12.

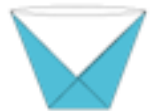

Obr 8: Origami pohárik

\section{Skúsenosti z vyučovacích hodín}

Počas overovania vzdelávacieho scenára sme zistili nasledujúce skutočnosti.

Pri skladaní čiapky bol najt’ažšie vykonatel'ný krok 2 (obrázok 9), pretože žiakom robilo problémy zohnút' horné vrcholy obdížnika presne ku osi strán. Táto os totiž nebola zložená tak, aby bola vypuklá, ale bola zohnutá smerom k podložke. Nevidiacim žiakom sa preto dala len t'ažko nahmatat'. Museli si papier prevrátit'. Postupovali sme tak, že pravý horný vrchol zohla vyučujúca a l'avý mali zohnút' žiaci samostatne. Ani to však nedokázali všetci urobit' dostatočne presne, okrem jedného. Nemali na to dostatočne vycvičený hmat. Napriek tomu sa žiakom skladanie čiapky páčilo a tešili sa, že doma si skúsia poskladat' novú čiapku z vel'kého kusa novinového papiera.
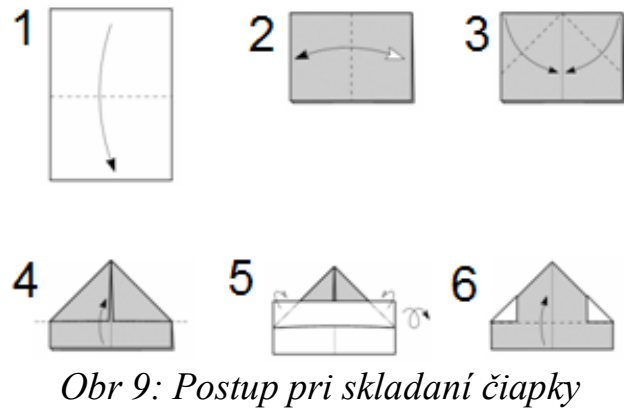

Pri skladaní lod'ky bol postup od kroku 7 (obrázok 10) vel'mi náročný pre učitel'a, $\mathrm{z}$ hl'adiska inštruovania žiakov a rovnako aj žiaci mali problémy jednotlivé inštrukcie presne vykonat'. Učitel' musel každú inštrukciu čiastočne vykonat' namiesto nich. Najúčinnejšou metódou bolo uchopit' žiakom ruky a pohybovat' nimi požadovaným spôsobom. Najtažší bol krok 11, pretože žiaci nedokázali manipulovat' iba s vrchnou vrstvou papiera.

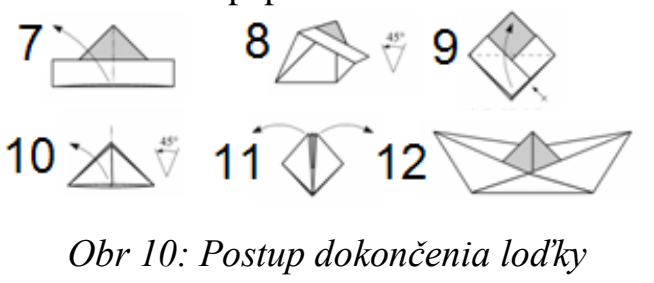

Pri skladaní srdiečka sa krok 2 (obrázok 11) podobal kroku 2 z postupu na skladanie čiapky (obrázok 9). Hoci sa žiaci s týmto krokom už stretli, opät' mali problémy, pretože os, ktorú mali nahmatat' nebola vypuklá. Museli opät' papier prevrátit'. Podobne to bolo aj v kroku 3. Pri krokoch 6 a 7 musel učitel' pohybovat' rukami žiakov potrebným spôsobom, aby pochopili, čo treba urobit'. Tiež sa osvedčila metóda - pravú stranu zloží učitel' a l'avú žiaci. 
1

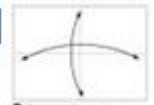

2

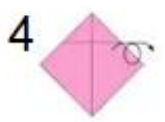

7

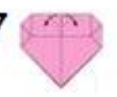

5
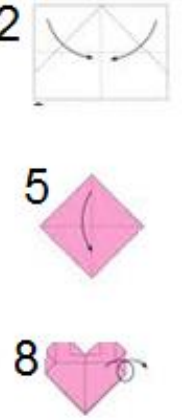

3

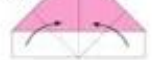

6

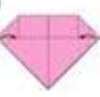

9

Obr 11: Postup pri skladaní srdiečka

Pri skladaní pohárika sa používal papier tvaru štvorca. My sme však mali $\mathrm{k}$ dispozícii papier tvaru obdížnika vel'kosti A4. Žiaci, ktorí neboli nevidiaci od narodenia, teoreticky ovládali postup ako z papiera tvaru obdížnika vytvorit' papier tvaru štvorca, ale prakticky to nedokázali realizovat' samostatne. Musel im pomôct' učitel'.

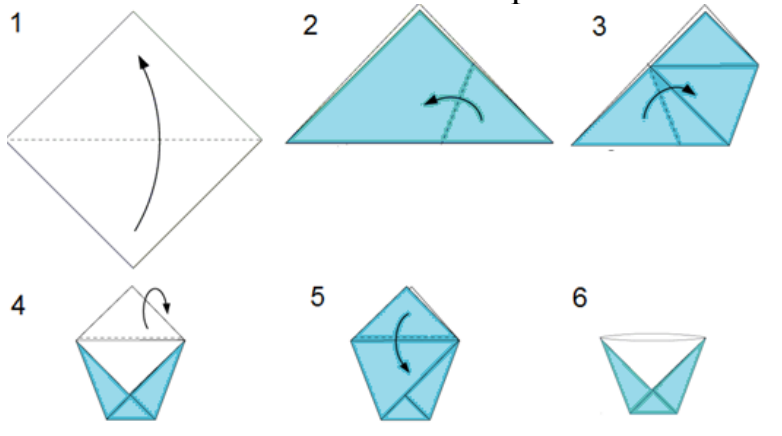

Obr 12: Postup pri skladani pohárika

Žiaci nemali potrebný cit pre odtrhnutie prevyšujúcej časti papiera. Pre začiatočníkov je lepšie, ak má učitel' papier v tvare štvorca pre každého žiaka už vopred pripravený. Najnáročnejším krokom bol krok 3 - zloženie spodného vrcholu ku protil'ahlej strane. Žiaci nevedeli kam presne treba vrchol priložit'. Opät' jeden vrchol (pravý) zohol učitel' a druhý vrchol (l'avý) už žiaci dokázali zohnút' samostatne. V kroku 5 niektorí žiaci intuitívne prišli na to, čo treba urobit'. Nakoniec sa žiaci vel'mi tešili $\mathrm{z}$ hotového pohárika.

Počas našich hodín sme zistili nasledujúce skutočnosti.

- Zvolené skladačky boli dostatočne motivujúce a tvary výsledných predmetov boli dostatočne zrozumitel'né pre nevidiacich.

- Skladanie origami sa žiakom páčilo, aj ked' robili chyby - nepresne skladali papier. Bolo vidiet', že nemajú prsty na takúto činnost' dostatočne vycvičené. Nemali so skladaním papiera vôbec žiadne skúsenosti a ani potrebný cit $\mathrm{v}$ rukách.
- Jedna žiačka sa natol'ko nadchla pre skladanie origami, že si doma poskladala všetky skladačky ešte raz. Iná žiačka sa snažila vykonat' jednotlivé kroky čo najrýchlejšie, aby mala výsledný predmet čo najskôr hotový. Bolo to však na úkor presnosti a výsledok nebol pekný. Žiačky sa vd'aka tomu naučili, že presnost' a precíznost' je pri práci robota vel'mi dôležitá.

- Mnohé problémy pri skladaní (krok 3 pri čiapke a srdiečku) nastali z toho dôvodu, že sme nedali pozor, aby zhyby, ktoré bolo treba nahmatat', boli vyčnievajúce, a nie smerom ku podložke.

Z hl'adiska rozvoja algoritmického myslenia žiaci pochopili, že inštrukcie musia byt' zrozumitel'né a presné a tiež aj dôsledne vykonané. Pochopili tiež, že dôležité je aj správne poradie krokov a to sme chceli dosiahnut'.

$\mathrm{Na}$ základe našich zistení sformulujeme odporúčania pre d'alšiu intervenciu.

Je potrebné, aby si žiaci najprv osvojili základnú terminológiu a základné slovné povely. Bez tejto fázy je slovné inštruovanie t’ažko pochopitel'né.

- Začiatočníci musia začat' s jednoduchšími skladačkami - iba zohýbat' papier na polovicu cez stredy strán alebo po uhlopriečke, prípadne rohy ku stredovej osi. Po tejto úvodnej fáze môžu žiaci skladat' čiapku a pohárik, pretože sú relatívne rýchlo hotové a žiačky si dokážu zapamätat' celý postup. Skladanie lod'ky a srdiečka je vhodné pre pokročilejších žiakov.

- Pri inštruovaní sa nám najviac osvedčila metóda uvedená na konci predchádzajúcej kapitoly - skladat' súčasne so žiakmi a výsledok každého kroku im nechat' ohmatat'.

- Odporúčame postup viackrát zopakovat'. Ideálne je, ak žiaci hotový objekt opatrne rozložia a poskladajú ho znova. Podl'a našich skúseností väčšina žiakov zvládne samostatne vykonat' postup až pri tret'om skladaní.

Nenásilnou formou môžeme zaviest' aj koncept podmienený príkaz.

- Ak žiaci nemôžu nahmatat' požadovaný zlom papiera, musia si prevrátit' papier („Ak nedokážeš nahmatat' zlom papiera, prevrát' ho"). 
- Ak sa žiakom nepodarí poskladat' požadovaný objekt, musia sa vrátit' o niekol'ko krokov naspät' alebo na začiatok („Ak tvoja skladačka nemá požadovaný tvar, vrát' sa na krok ...")

\section{Záver}

Po preštudovaní uvedených zdrojov a na základe získaných skúseností môžeme konštatovat', že metóda skladania origami je vhodná pre budovanie niektorých informatických konceptov u nevidiacich žiakov, akými sú inštrukcia, postupnost' inštrukcií, návod. Treba si však vyhradit' dostatočné množstvo vyučovacích hodín. Spočiatku treba žiakov naučit' základné úkony potrebné pri práci s papierom a vysvetlit základné slovné inštrukcie.

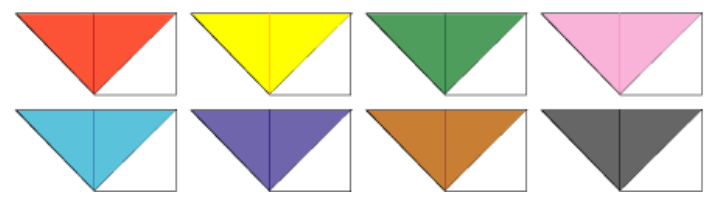

Obr 13: Osem rovnakých častí vytvorí hviezdu

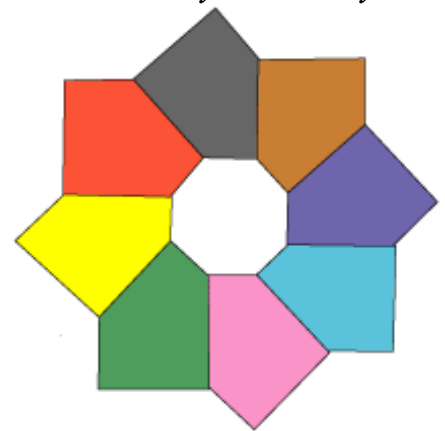

Obr 14: Výsledná hviezda [10]

Sme toho názoru, že začat' skladat' origami až na druhom stupni ZŠ je neskoro. Tejto činnosti by sa mali nevidiaci žiaci venovat' $\mathrm{v}$ každom ročníku základnej školy už aj na prvom stupni ZŠ, aby sa cvičila ich manuálna zručnost' a jemná motorika. Tiež by sa postupne oboznamovali aj s potrebnou terminológiou. Vo vyšších ročníkoch by neboli limitovaní vlastnou nešikovnost'ou a mohli by sa viac sústredit' na pojmy súvisiace s geometrickými tvarmi a algoritmami. Zručnejší žiaci by dokázali poskladat' aj komplikovanejšie objekty pozostávajúce $\mathrm{z}$ viacerých menších častí. $\mathrm{Z}$ hl'adiska informatických konceptov by sa takto dal zaviest' aj pojem cyklus (obr. 13. a 14.).

Veríme, že aktivity, ktoré sme uviedli, ocenia nielen učitelia nevidiacich žiakov, ale aj učitelia $\mathrm{v}$ bežných školách. Aj pre vidiace deti by mohla byt' zaujímavá aktivita skladanie origami naslepo so zaviazanými očami, len na základe slovných inštrukcií. Takýmto spôsobom by sa tiež hrali na skladacieho robota, ktorý nič nevidí, ale iba vykonáva inštrukcie.

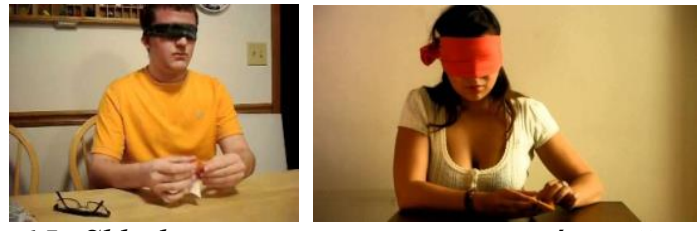

Obr 15: Skladanie orgiami so zaviazanými očami (originál je na www.youtube.com)

Inou aktivitou by mohlo byt' vytváranie obrázkového návodu zorad'ovaním hotových obrázkov do správneho poradia. Po vytvorení návodu by žiaci podl'a neho poskladali skladačku, čím by aj overili jeho správnost'.

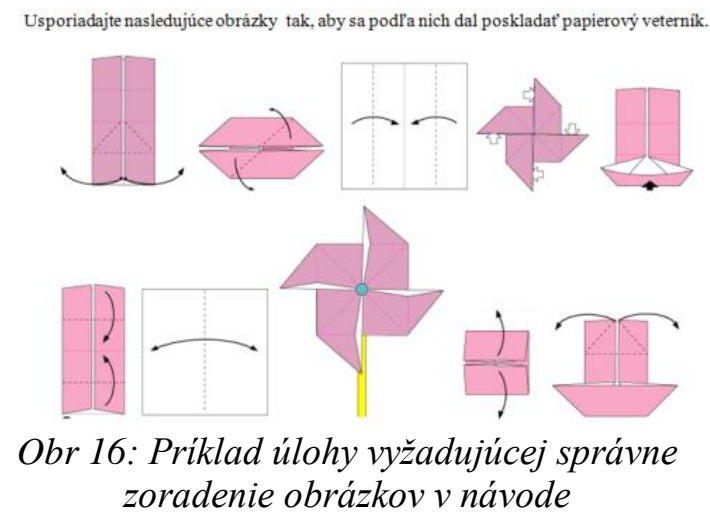

Zaujímavou činnost'ou so staršími žiakmi by mohla byt' tvorba rôznych typov návodov textový, obrázkový, animovaný, video a diskutovanie o tom, ktorý návod je najviac zrozumitel'ný a prečo. Môžeme sa tiež s det'mi pokúsit' vymysliet' vhodné inštrukcie pre origami robota (stručné, jasné, úplné).

\section{Literatúra}

[1] BALKCOM, D. J. et al.: Robotic origami folding. In International Journal of Robotics Research 27(5):613-627 (2008) (online). [cit. 2013-11-25]. URL : <http://www.cs.dartmouth. edu/ devin/papers/djb-ijrr2008.pdf>

[2] British Origami Society. URL: <http://www.britishorigami.info/practical/diagra ms/phone.php> [cit. 2013-11-25].

[3] JAKABČIC, I. - POŽÁR, L. Všeobecná patopsychológia. Patopsychológia mentálne postihnutých. Bratislava: IRIS, 1996. 194 s. ISBN 80-88778-11-5.

[4] Japonské origami pomáhá nevidomým (online). URL: <http://www.alfabet.cz/index.php/ informacni-servis-pro-rodice/32-anopress-it/182japonske-origami-pomahaji-nevidomym $>$ [cit. 2013-11-25]. 
[5] KALAŠ I. et al. Premeny školy v digitálnom veku, SPN - Mladé letá, Bratislava, 2013. ISBN: 9788010024094

[6] LAVOIE, Ch. Origami Computational Model (online). [cit. 2013-11-25]. URL : <http://cgm. cs.mcgill.ca/ athens/cs507/Projects/2002/Christi anLavoie/>

[7] LOVÁSZOVÁ, G. Origami, matematika a programovanie. In: Huraj, L. Didinfo 2003. UMB Banská Bystrica. ISBN 80-8055-786-1. (2003), s.64-67.

[8] MEYER, J. Using Making Directions for Origami as an Example in Teaching Programming, Talk given at Conference on Origami for Education and Therapy (COET) 2004, New York City, June 29, 2004 (online). [cit. 2013-1125]. URL : <http://faculty.purchase.edu/jeanine. meyer/origami/>

[9] MOJŽÍŠEK, J. Návody ke skládankám z papíru bez užití obrázků (online). [cit. 2013-1125]. URL: <http://mojzisek.braillnet.cz/origami/> [10] Origami club. URL: <http://en.origamiclub.com/> [cit. 2013-11-25].

[11] Origami, aneb jak rozvíjet svůj hmat?, Tyfloservis Hradec Králové (online). [cit. 201306-03]. URL : <http://www.tyfloservis.cz/aktuali ty.php>

[12] Photo Essay: Folding Origami With the Blind, (online). [cit. 2010-02-18]. URL : <http://thefutureisred.typepad.com/onedayatatim e/2010/02/photo-essay-folding-origami-with-theblind.html>

[13] POŽÁR, L. Patopsychológia - psychológia jedincov srôznym druhom postihnutia. Bratislava : MABAG, 2003. ISBN 80-89113-07-9 [14] REGEC, V. Praktické využitie informačných a komunikačných technológii u žiakov so zrakovým postihnutím. Dizertačná práca, Pedagogická fakulta Univerzity Palackého, Olomouc 2010

[15] ŘEZNÍČKOVÁ, M. Zrakovo postihnuté diet’a In Koluchová, J. et. al. Přehled patopsychologie ditěte II. Praha. Státní pedagogické nakladatelství. 1989. s 40-64.

[16] Scottish Sensory Centre. URL: <www.ssc.education.ed.ac.uk> [cit. 2010-11-11]. [17] SKÖLD, B. C. Picture books accessible to blind and visually impaired children. In World Library And Information Congress: 73rd Ifla General Conference And Council, 19-23 August 2007, Durban, South Africa, (online). [cit. 201311-25]. URL : <http://www.ifla.org/IV/ifla73>

[18] SMITH, J. S. An Origami Instruction Language, British Origami Society. 1975. (online). [cit. 2013-11-25]. URL : <http://www. nickrobinson.info/clients/smithy/oil/oil.php>

[19] Štátny vzdelávací program. Informatická výchova, (online). [cit. 2013-11-25]. URL : <http://www.statpedu.sk/files/documents/svp/ 1stzs/isced1/vzdelavacie_oblasti/informaticka_ vychova_isced1.pdf>

[20] Štátny vzdelávací program. Informatika, (online). [cit. 2013-11-25]. URL : http://www. statpedu.sk/files/documents/svp/2stzs/isced2/vzd elavacie_oblasti/informatika_isced2.pdf >

[21] Tyfloservis. URL: <http://www.tyfloservis. cz/aktuality.php> [cit. 2013-11-25].

[22] VÍTKOVÁ, M. Speciální pedagogika $\mathrm{v}$ raném a předškolním věku se zřetelem na rozvoj výtvarných aktivit. Brno: Masarykova univerzita v Brně, 1993.

[23] Web Accessibility in Mind. URL: http://webaim.org/articles/cognitive/activity [cit. 2013-11-25].

RNDr. Ludmila Jašková, Ph.D.

Katedra základov a vyučovania informatiky

Fakulta matematiky, fyziky a informatikyUK

Mlynská dolina

842 43, Bratislava, SR

Tel: +421 260295306

E-mail: jaskova@fmph.uniba.sk

Www pracoviště: www.edi.fmph.uniba.sk 